\title{
CONTENIDO DE LOS CÓDIGOS DEONTOLÓGICOS
}

\author{
Juan Carlos Riofrío Martínez-Villalba
}

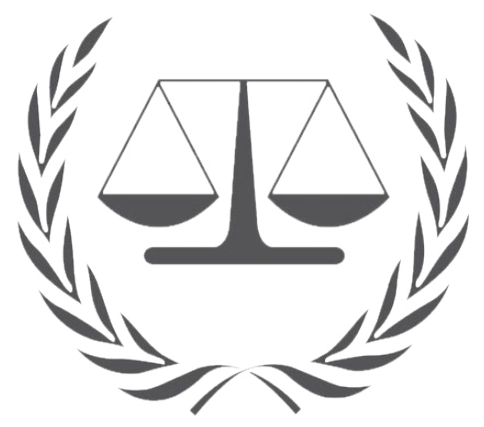

$\longrightarrow$ omo se sabe, desde la entrada en vigencia de la Ley Orgánica de Comunicación (LOC), por el ministerio del art. 9 todos los medios de comunicación se han visto obligados a expedir sus propios códigos deontológicos. La nueva exigencia del art. 9 está orientada a «mejorar sus prácticas de gestión interna y su trabajo comunicacional», según las pautas marcadas por el art. 10 de la misma Ley. Después de haber analizado varios códigos deontológicos cuya identidad prefiero mantener en reserva, vierto aquí algunas reflexiones sobre el sentido y operatividad de esta exigencia, para luego analizar brevemente cuál es el contenido mínimo que estos códigos deben tener.

\section{La obligación de dictar un código deontológico}

Los códigos deontológicos son esencialmente normas morales o éticas de conducta para las diferentes profesiones. Como normas éticas, su validez y vigencia no se anclan en la validez y vigencia de la ley positiva. Deberían incluir normas morales que cualquier persona sensata considere razonables. Este contenido puede tener diversos grados de fuerza jurídica: puede ser una mera declaración que serviría como pauta o guide line de conducta (con diversos efectos, como el de determinar el contenido práctico del principio jurídico de buena fe; además pueden ser códigos 
pactados por un grupo de profesionales, con lo cual el adquiriría la fuerza de un contrato, y si es adoptado por una junta de accionistas tendría un valor semejante al de un estatuto social. Muchas leyes extranjeras miran con buenos ojos estos códigos y les conceden un valor especial, elevando su fuerza incluso hasta un nivel reglamentario y hasta cuasilegal. En cambio, es menos común que se imponga a cada institución tener uno.

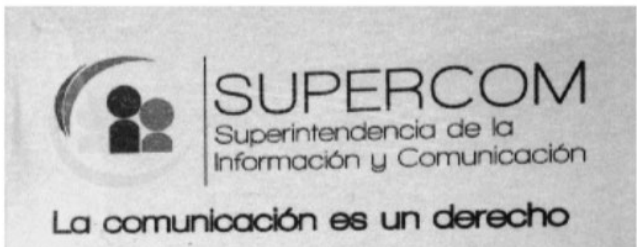

\section{Ley Orgánica de Comunicación}

\section{Reglamento General a la Ley Orgánica de Comunicación}

\author{
En junio de 2013, la Ley Orgánica \\ de Comunicaciónsería aprobada \\ con 108 votos en la Asamblea. Nacional
}

Resulta discutible una obligación tan generalizada de expedir un código deontológico a todos los medios de comunicación. Hay medios de comunicación muy pequeños donde solo labora una persona, a la cual no sería razonable exigirle que redacte un código deontológico de prácticas comunicacionales, para acordar con ella misma aquello a lo que ella voluntariamente ha de atenerse. Aunque el art. 9 de la LOC solo habla de "medios de comunicación" (excluyendo la palabra "social"), enconcordancia con otros artículos de la misma ley (v. gr. el art. 16), ha de entenderse que la obligación de emitir tales códigos no cae sino en quienes son "medios de comunicación social" porcumplirlos requisitos previstos en el art. 5 de la LOC.

El Reglamento a la LOC del 2014 en su art. 8 manda a los medios de comunicación presentar su código deontológico el último día del año de creación del medio. Además estableceunacuestionableobligación retroactiva demostrartalcódigoduranteelaño 2013.

¿Qué pasaría si un medio de comunicación no emite código deontológico alguno? A más de alguna eventual sanción por el incumplimiento de la ley, parece obvio que no quedaría vinculado a código deontológico alguno, porque la naturaleza jurídica de estos códigos es la de nacer de la voluntad de las personas involucradas en una empresa, proyecto, asociación o ente moral. Por supuesto, esto no significa que los comunicadores no estén sujetos a ninguna norma. El art. 10 señala que «todas las personas naturales o jurídicas que participen en el proceso comunicacional deberán considerar las siguientes normas mínimas (...)» y que «el incumplimiento de las normas deontológicas establecidas en este artículo podrá ser denunciado por cualquier ciudadano u organización ante la 
Superintendencia de la Información y Comunicación» (§2). Es decir, el art. 10 obliga porque es ley, no porque sea ningún código "tácito".

Veamos ahora el caso contrario: ¿qué pasaría si un medio de comunicación sí emite un código deontológico, pero añade en él muchas otras cláusulas no previstas en el art. 10 de la LOC, cosa que sucede con mucha frecuencia? ¿Podría acaso la Superintendencia de la Información y Comunicación perseguir al medio por no cumplir con sus propias normas, aquellas que decidió libremente y que libremente podría cambiar? No creemos que esto sea razonable. La competencia de las instituciones públicas, y más aún la competencia para sancionar, nace stricto sensu de la ley; no caben aquí interpretaciones amplias, porque rige aquí el principio constitucional in dubio pro reo. Por lo demás, el art. 10 no dice que toda norma deontológica será exigida por las autoridades, sino sólo aquellas «normas deontológicas establecidas en este artículo». Por lo demás, una cosa son las obligaciones previstas en el art. 10, que son obligatorias por ser ley, y otra la obligación de expedir un código deontológico que contenga las normas del art. 10. Ahí no se dice que se juzgará a los medios según lo escrito en el código deontológico, sino a «las personas» por incumplir el art. 10. Sin embargo, por el temor a que se persiga al medio por no cumplir su propio código deontológico, en la práctica algunos han optado por expedir códigos exactamente iguales al art. 10 de la LOC, añadiendo quizás algunas otras disposiciones igualmente previstas en la ley. Intentan evitar de esta manera añadir más cargas que las que la LOC ya impone al cada vez más riesgoso trabajo comunicativo.

Finalmente, obsérvese que si se incumplen las normas deontológicas del art. 10 la Superintendencia de la Información y Comunicación sólo «emitirá una amonestación escrita» (art. 10). Para poner una sanción mayor deberá constatarse que hay «una infracción que amerite otra sanción o medida administrativa establecida en esta Ley» (ibid.). Nulla poena sine lege, no toda maldad debe ser sancionada, sino solo las que se encuentran tipificadas en la ley.

\section{Figuras distintas a los códigos deontológicos}

Sobre el papel se puede escribir todo: novelas rosa, normas deontológicas, chistes, pecados y otras cuestiones de conciencia, normas de etiqueta o de estilo, etc. Pero por el hecho de escribir todo eso junto, en un código, no hace que todo ello sea "norma deontológica". Conviene mucho, para efectos tanto teóricos como prácticos, distinguir cuatro conceptos: el de código deontológico, el de manual de estilo, el de ideario del medio y el de cláusula de conciencia. Tras haber dicho que código deontológico es esencialmente un conjunto de cláusulas morales o éticas de conducta para las diferentes profesiones, entramos a ver el resto de conceptos.

a) Manual de estilo o guía editorial

El Reglamento a la LOC, art. 8, señala que «el manual de estilo o guía editorial forma parte del código deontológico. Los medios de comunicación distribuirán sus códigos 
Un Manual de Estilo se encargará de dictar normas que rijan el diseño y la redacción de un documento en concreto

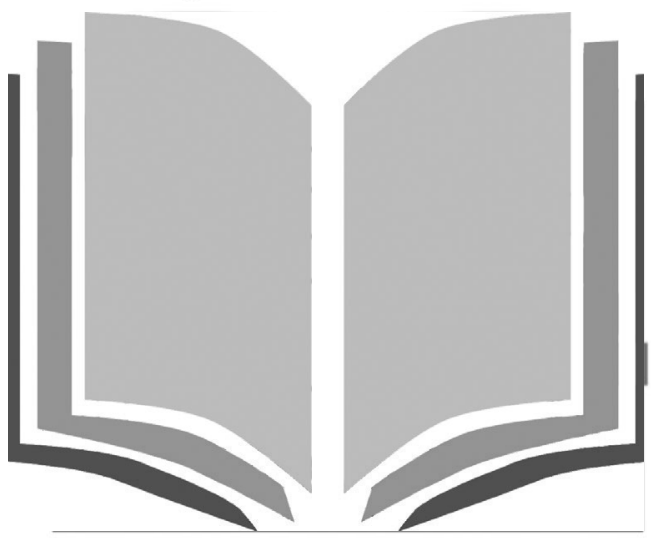

deontológicos a todos sus trabajadores y colaboradores, y serán publicados en su página web si la tuviere». Se establece de forma reglamentaria una obligación que no consta en la Ley y que resulta absolutamente inadecuada. Como se sabe, estos manuales son una guía compuesta por un conjunto de criterios, normas de diseño y de redacción de documentos, para ser utilizados por los redactores de periódicos u otras organizaciones que también publican textos. Tales manuales no tienen que ver con la ética, ni con los valores, ni con el derecho, sino con la forma de exposición de las ideas. Lo mismo habría de decirse de las guías editoriales, que además recogen una lista de procesos y formas de gestión muy variada para elaborar noticias, reportajes, entrevistas, etc. Sería un despropósito permitir que basados en el art. 10 de la LOG se le permitiera al público denunciar ante la Superintendencia una falta de estilo o por no llenar un formulario previsto en la guía editorial. Los reglamentos no pueden fijar de manera gratuita, sin pie en la ley, una obligación como esta que linda con el derecho a fundar libremente los medios, a la libertad de expresión, a la libertad de prensa y a otros derechos constitucionales, y que por lo tanto solo se puede establecer a través de una ley orgánica (según lo exigido en los arts. 132 y 133 de la Constitución de la República del Ecuador).

\section{b) Ideario}

El ideario de un medio es su filosofía, las convicciones profesadas, las opiniones sobre temas fundamentales compartidas por quienes emprenden un proyecto comunicacional. Estas pueden ser verdes, rojas, azules... de izquierda, derecha, centro, centro izquierdo, centro derecho... anárquicas, monárquicas, democráticas... ¡Lo que sea! Obsérvese cómo estas cosas son diversas a la ética delmedio. Elderecho a profesarcualquier

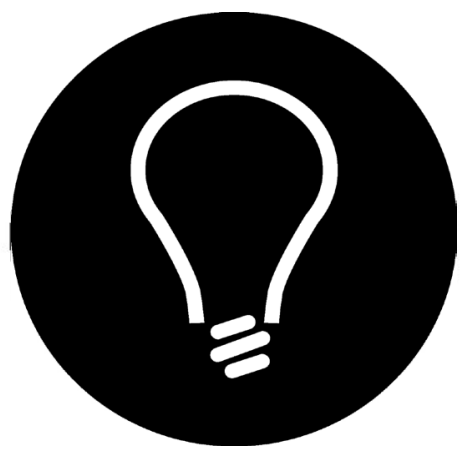

Por otra parte, el Ideario se refiere convicción de conciencia está protegido al coniunto de ideas v obiniones de los autores a nivel constitucional (vid. Art. 66, num. 12 y art. 20 de la Constitución), porque todos tenemos derecho a actuar en conciencia, tanto los individuos considerados 
aisladamente, como los que se han asociado para fundar una escuela, universidad, medio de comunicación, etc. Un ideario escrito en blanco y negro constituye la mejor prueba de orientación ideológica, de convicciones profesadas, de opiniones compartidas por los fundadores del medio. El ideario suele estar contenido in nuce, de manera muy genérica, dentro del capítulo "Objetivos", "Misión", "Visión" que algunos códigos deontológicos ecuatorianos incluyen. Sin duda dan derecho a la cláusula de conciencia del colectivo que se autoimpone ese ideario.

La LOG, art. 9, obliga a expedir un código deontológico, pero no un ideario. Además, la ley prevé que se juzgará al medio de comunicación según su mismo código deontológico. Por lo dicho, no conviene que en la práctica se incluya el ideario del medio dentro del código deontológico, sino que se haga en documentos separados.

c) Cláusula de conciencia

Vale ahora parar en la llamada "cláusula de conciencia", regulada en el art. 39 de nuestra LOC. Se trata de un derecho de toda persona, consagrado de manera general en la Constitución, art. 66, num. 12, como "objeción de conciencia” y específicamente para la actividad comunicacional en el art. 20 de la Constitución. En ambos casos se dice que es un derecho de «toda persona» (la LOC, art. 39, se queda chica en este punto, al solo hablar de las y los «comunicadores sociales», por lo que habrá que hacer una interpretación extensiva, de tal manera que se entienda que "comunicador social" es toda persona que informe a la sociedad).

La pionera en regular la cláusula de conciencia del periodista fue Francia. En ese revolucionario país se consideró que cuando un periodista decidía trabajar con un medio de comunicación, lo hacía bajo el entendido de que trabajaba ahí y no en otro lado, porque compartía la ideología de ese medio en concreto. Es por esta razón que si el medio de comunicación cambiaba su línea ideológica, ello suponía una ruptura del contrato de trabajo, y el periodista podía acudir a los tribunales para demandar las indemnizaciones propias de un despido intempestivo. La cláusula también le permitía negarse a participar en la elaboración de informaciones contrarias a los principios éticos de las comunicaciones. Tales políticas pronto se fueron acoplando en otros países europeos y hoy constan leyes sobre la materia en España, Portugal, Hungría, Austria, Checoslovaquia y Alemania.

Los mencionados desarrollos históricos de la cláusula de conciencia se encuentran incluidos en la LOC, art. 39, al decir que el ejercicio de esta cláusula no puede considerarse causal de despido, está diciendo que si fuera considerada así subjetivamente por el empleador (o esta fuera la razón del despido), luego estaríamos ante un despido intempestivo con todas sus consecuencias en temas administrativos, civiles y de indemnizaciones. También la LOC, art. 39, recoge el parámetro de los principios éticos de las comunicaciones, especialmente los fijados en el código deontológico del medio. 
Según la doctrina tradicional, tres son las consecuencias que tiene la cláusula de conciencia: (i) las personas tienen derecho a fundar medios de comunicación, partidos políticos, instituciones educativas, etc. con una línea editorial adecuada a sus propias convicciones; (ii) en consecuencia, tales personas, empresas y medios tienen derecho a que quienes laboran con ellas respeten su ideario; y, (iii) en el otro extremo de la relación, quienes trabajan o colaboran en las empresas o medios de comunicación tienen derecho a que los directores no les exijan actos que vayan en contra de su conciencia. Es decir, el respeto debe ser mutuo entre directores y dirigidos. El art. 39 de la LOC recoge estas consecuencias, aunque no tan explícitamente: el inciso 1 parece hablar más de la conciencia del informador, mientras el inciso 2 refuerza la conciencia de las personas que integran el medio y que se plasma en el código deontológico.

Desde el punto de vista del medio de comunicación, Bell Mallen, Corredoira y Alfonso \& Cousido (1992) señalan que para que la cláusula de conciencia opere, es necesario que se den dos condiciones: primero, que exista de forma clara una línea editorial previa al contrato con el periodista y, segundo, que el periodista la acepte (cfr. también Desantes et al., 1994, p. 264). Nieto Tamargo (1968, pp. 1-23; 1969, pp. 173-219) ya había insistido en que los principios ideológicos deben ser propuestos, no impuestos, a la redacción, ya que de ser obligado su cumplimiento, el compromiso del que él mismo habla, sería ficticio y las consecuencias negativas. Sin un ideario escrito es difícil que la empresa pueda probar cuál es en concreto su línea editorial; podría hacerlo mostrando algún documento donde se ha fijado la misión y visión de la empresa, pero tales cosas generalmente son demasiado abstractas. En cualquier caso, la prueba debe estar encaminada a probar que desde que el trabajador entró a la empresa o desde que el colaborador participó en ella, desde ese momento sabía, o debía conocer, cuál es la línea editorial.

En la objeción de conciencia general (que en nuestro derecho está prevista en la Constitución, art. 66, num. 12), para que la persona pueda interponerla, también debe probar que ese tema solicitado atenta contra su conciencia. Suele exigirse una cierta gravedad o peso de conciencia, proporcional al acto exigido. Muchas objeciones se han caído en diversos campos por falta de prueba sobre el peso que ejerce en la conciencia la comisión de un acto. En el caso de la conciencia sobre temas de información la prueba en este sentido siempre ha sido más amortiguada, pues aquí se protege también la libertad de expresión de pensamiento, de credo, de opinión, también la libertad de expresión de pensamiento, de credo, de opinión, que fácilmente justifican la excusa de no informar lo que se considera falso. Esto es una aplicación práctica de los principios de veracidad y de honestidad informativa.

Como todo derecho, este también tiene sus límites. El art. 66, num. 12, de la Constitución dice que el ejercicio de la objeción de conciencia «no podrá menoscabar otros derechos, ni causar daño a las personas». Esto va de lado y lado. No debe haber daño para el informador, ni para el medio, ni tampoco para la sociedad. La cláusula 
de conciencia no da derecho a la vagancia, a no trabajar. A un periodista que se ha negado a cubrir una noticia por temas de conciencia, se le puede pedir que realice otro trabajo compensatorio.

Elrespetomutuoque debehaber entreinformanteymedio, delque anteshablábamos, además implica que ninguno de los dos puede hacer una guerra solapada. No estaría bien que el periodista se dedique a desprestigiar el medio, ni el medio al periodista, por el solo hecho de no compartir una opinión. Con todo, como dice la LOC en su art. 39 — quizá cargando las tintas a favor del informante — los comunicadores mantienen el derecho «a hacer público su desacuerdo con el medio de comunicación social». No es muy acertado, por contrariar probablemente el código deontológico del medio y por violentar varios parámetros constitucionales y de derechos humanos, es que ese desacuerdo se pueda hacer «a través del propio medio» (LOC, art. 39).

\section{Contenido mínimo de los códigos}

$\mathrm{El}$ art. 10 de la LOC consagra una serie de normas deontológicas "mínimas" a la que los comunicadores deben atenerse. Por su importancia, vale recordarlas:

Art. 10. Normas deontológicas.- Todaslas personas naturales ojurídicas que participen en el proceso comunicacional deberán considerar las siguientes normas mínimas, de acuerdo a las características propias de los medios que utilizan para difundir información y opiniones:

1. Referidos a la dignidad humana:

a. Respetar la honra y la reputación de las personas;

b. Abstenerse de realizar y difundir contenidos y comentarios discriminatorios; $\mathrm{y}$,

c. Respetar la intimidad personal y familiar.

2. Relacionados con los grupos de atención prioritaria:

a. No incitar a que los niños, niñas y adolescentes imiten comportamientos perjudiciales o peligrosos para su salud;

b. Abstenerse de usar y difundir imágenes o menciones identificativas que atenten contra la dignidad o los derechos de las personas con graves patologías o discapacidades;

c. Evitar la representación positiva o avalorativa de escenas donde se haga burla de discapacidades físicas o psíquicas de las personas;

d. Abstenerse de emitir imágenes o menciones identificativas de niños, niñas y adolescentes como autores, testigos o víctimas de actos ilícitos; salvo el caso que, en aplicación del interés superior del niño, sea dispuesto por autoridad competente; 
e. Proteger el derecho a la imagen y privacidad de adolescentes en conflicto con la ley penal, en concordancia con las disposiciones del Código de la Niñez y Adolescencia; y,

f. Abstenerse de emitir contenidos que atenten contra la dignidad de los adultos mayores, o proyecten una visión negativa del envejecimiento.

3. Concernientes al ejercicio profesional:

a. Respetar los presupuestos constitucionales de verificación, oportunidad, contextualización y contrastación en la difusión de información de relevancia pública o interés general;

b. Abstenerse de omitir y tergiversar intencionalmente elementos de la información u opiniones difundidas;

c. Abstenerse de obtener información o imágenes con métodos ilícitos;

d. Evitar un tratamiento morboso a la información sobre crímenes, accidentes, catástrofes u otros eventos similares;

e. Defender y ejercer el derecho a la cláusula de conciencia;

f. Impedir la censura en cualquiera de sus formas, independientemente de quien pretenda realizarla;

g. No aceptar presiones externas en el cumplimiento de la labor periodística;

h. Ejercer y respetar los derechos a la reserva de fuente y el secreto profesional;

i. Abstenerse de usar la condición de periodista o comunicador social para obtener beneficios personales;

\section{Consistencia Disc Integridad Fluidez Segur Asertivic Audacia Confianza Solvencia Coopera Humildad Visión


j. No utilizar en provecho propio información privilegiada, obtenida en forma confidencial en el ejercicio de su función informativa; y,

k. Respetar los derechos de autor y las normas de citas.

4. Relacionados con las prácticas de los medios de comunicación social:

a. Respetar la libertad de expresión, de comentario y de crítica;

b. Rectificar, a la brevedad posible, las informaciones que se hayan demostrado como falsas o erróneas;

c. Respetar el derecho a la presunción de inocencia;

d. Abstenerse de difundir publireportajes como sifuese material informativo;

e. Cuidar que los titulares sean coherentes y consistentes con el contenido de las noticias;

f. Distinguir de forma inequívoca entre noticias y opiniones;

g. Distinguir claramente entre el material informativo, el material editorial y el material comercial o publicitario;

h. Evitar difundir, de forma positiva o avalorativa, las conductasirresponsables con el medio ambiente;

i. Asumir la responsabilidad de la información y opiniones que se difundan; y,

j. Abstenerse de realizar prácticas de linchamiento mediático, entendiendo por tales, la difusión de información concertada y reiterativa, de manera directa o por terceros, a través de los medios de comunicación destinada a desprestigiar a una persona natural o jurídica o reducir su credibilidad pública.

\section{plina Prudencia}

idad Exactitud

ad Curiosidad

Rigor

Lealtad

Eficacia

ixcelencia

ción

Libertad

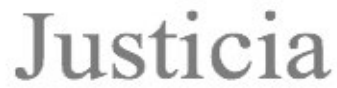

ión

ión Honor Servicio

Profesionalismo

Contribución

dentro de los códigos deontológicos de cualquier profesión.

dentro del área del periodismo y la comunicación 
El incumplimiento de las normas deontológicas establecidas en este artículo podrá ser denunciado por cualquier ciudadano u organización ante la Superintendencia de la Informacióny Comunicación, la que, luego de comprobarla veracidad delodenunciado, emitirá una amonestación escrita, siempre que no constituya una infracción que amerite otra sanción o medida administrativa establecida en esta Ley.

Tal como están escritos estos principios, son sumamente razonables y es muy conveniente que todo código deontológico los tenga. Convendrá mucho cuidar que la jurisprudencia los desarrolle con el mejor tino, pues en estos temas los desatinos pueden ser grandes. Una cuestión delicada es la de determinar si los códigos deontológicos pueden contrariar eventualmente lo dispuesto en el art. 10 — que, insisto, considero sumamente razonable-, o cualquier otra norma, o si en cambio los medios están constreñidos a pensar como piensa el legislador, a hacerle venias a su buena o mala ideología. Una vez más, aquí ha de hacerse valer la libertad constitucional de pensamiento, de opinión, de convicciones, de expresión, etc. «Estos códigos deberán considerar las normas establecidas en el artículo 10 de esta Ley» (dice el art. 9), mas no hay obligación de someter la conciencia a ellas, pudiendo las normas codiciales regular esos mismos temas de forma diversa. En tal caso, la fuerza jurídica de esas líneas sería menor: obviamente no gozarán del respaldo de la ley, pues «los códigos deontológicos no pueden suplir a la ley». Por otro lado, recordando lo antes dicho, el art. 10 igual resultaría exigible por ser ley, mas no por ser código.

Ha de destacarse que todos los principios enunciados en la norma citada no gozan de una misma jerarquía. Si bien todos eventualmente pueden entrar en un juego y hasta ser un aporte mancomunado para resolver cada caso, es evidente que hay principios base, que de alguna manera son previos al resto. Por ejemplo, no se puede hablar de los límites para informar, si no hay derecho a informar. La libertad de expresión va ciertamente primero. En otro lugar (cfr. Riofrío, 2014, pp. 93-94) ya hemos observado que el fin primordial de la LOC es proteger «los derechos [constitucionales] a la comunicación, lainformaciónyla libertadde expresióny fortalecer la participación ciudadana» (LOG, Preámbulo, inciso 3). Sólo si se acepta la existencia de estos derechos, sólo entonces se puede proceder a analizar cuáles son sus límites.

Los límites del derecho a difundir informaciones son de dos tipos: objetivos y subjetivos. Los objetivos derivan de la naturaleza de la comunicación considerada en abstracto, sin tomar en cuenta nada más. En cambio, los subjetivos analizan cuáles son los derechos de los sujetos implicados en cada comunicación particular. Por eso, los límites objetivos tienenuna dimensión erga omnes mayor que los límites subjetivos, donde resulta más propio la acción personal que la popular. A continuación ofrecemos una breve explicación de estos límites.

\section{a) Límites subjetivos}

En síntesis los límites subjetivos son los derechos subjetivos. Si una información daña un derecho de una persona o de cualquier sujeto de derecho, entonces no hay derecho 
a que la información circule. Varios de estos derechos están recogidos por el art. 10 de la LOC, antes transcrito, pero no todos.

Entre estos derechos tenemos: (i) El derecho a la intimidad y la privacidad, cuya esfera de acción es más grande. Las personas jurídicas no tienen intimidad, pero sí pueden tener privacidad (cfr. Riofrío, 2008). (ii) El honor, la honra, la fama, el goodwill, el prestigio, etc. (iii) El derecho a la imagen y a la voz. (iv) Los derechos de competencia, especialmente los de competencia desleal, el derecho de la publicidad y el derecho de los consumidores, donde se exige un alto grado de veracidad en las informaciones. (v) El derecho a la identidad física, psicológica, cultural, etc. de los individuos y de los colectivos. (vi) El derecho a un desarrollo equilibrado, especialmente de los niños y adolescentes. (vii) El derecho a la paz, por el que la transmisión de escenas terroristas, morbosas, o que hacen apología del delito tienen una regulación especial. (viii) En general, el derecho de todos a no ser conculcado en su patrimonio, ni en sus derechos. Especial atención da el art. 10, num. 2 a aquellos derechos pertenecientes a los "grupos de atención prioritaria", los mismos que están definidos en el Título II de los "Derechos", Capítulo II de los "Derechos de las personas y grupos de atención prioritaria".

Los mencionados derechos también se encuentran reconocidos de forma desperdigada en otros arts. de la LOC, en la Constitución de la República y en otras normas de nuestro ordenamiento jurídico.

b) Límites objetivos: los principios generales

Los límites objetivos están recogidos en el art. 10 de la LOG y en otros lugares de la misma ley, como el art. 22. Coinciden en buena parte con los principios generales de la comunicación, que nacen de la misma naturaleza de la comunicación. Es decir, son preexisten a la ley y son propios de toda comunicación. La mayoría de los códigos deontológicos ecuatorianos recogen parte de estos principios generales de la información, aunque no siempre todos.

En primer lugar señalamos que toda comunicación se hace entre seres humanos, libres y responsables, para construir al ser humano, no para destruirlo. De ahí nacen cuatro principios básicos: (i) el de humanidad, de centralidad de la persona humana, de respeto de su dignidad; (ii) el de bien común informativo, por el que las comunicaciones deben estar fundadas en la verdad, la libertad, la justicia y la solidaridad; (iii) el de libertad comunicacional, por el que los seres humanos son libres de comunicarse entre sí, en tanto y cuanto buscan la verdad y el bien humano; y, (iv) el de responsabilidad, por el que quien informa es responsable de los efectos de su comunicación. La LOC bien hace en recoger estos principios y en prestarles su fuerza de ley positiva.

Desantes adopta una clasificación distinta, donde distingue un principio general por cada elemento de la comunicación (sujetos, medios y mensaje). Habla del principio de 
universalidad de los sujetos (todos tienen derecho a informar), del principio de universalidad de los medios (todos pueden informar por cualquier medio) y del principio de generalidad del mensaje (la mayoría de los mensajes puede circular, pero no todos), del que nace el principio in dubio pro informatione (por excepción algún mensaje no debe circular; en caso de duda debe respetarse la libertad para informar). Luego desglosa el principio de generalidad en 19 subprincipios (Desantes, 1994, pp. 14-17).

El mensaje (uno de los elementos de toda comunicación) también tiene sus propios principios específicos. A continuación ofrecemos nuestra propia clasificación de principios, la misma que recoge varios de los principios estudiados por los juristas y que se encuentran dispersos en el texto de la LOC y especialmente en los arts. $10 \mathrm{y}$ 22. Son los siguientes:

a) El primero, principal, central y cimentador de todos los principios es el de veracidad. La LOC, en su art. 22, lo deja entrever de varias maneras: en primer lugar, titula al artículo comentado como "Derecho a recibir información de relevancia pública veraz"; luego habla en este art. de varios de sus subprincipios (v. gr. dice que la información sea verificada, contrastada, precisa, contextualizada, etc.). En realidad la verdad es el valor supremo de la comunicación humana. Si la persona no fuera capaz de llegar a la verdad, la comunicación humana no tendría sentido. Quid est veritas? Desde hace siglos se entiende que la verdad es la adecuatio res ad mentem, la correcta adecuación de la mente con la cosa: es la conformidad entre la realidad y el pensamiento. Desde el punto de vista jurídico la verdad es un excelso bien y un altísimo valor jurídico a proteger, además de ser un derecho y un deber.

Todo ser humano tiene derecho a acceder libremente a la verdad, a conservarla, a orientarse y crecer en la verdad, a manifestarla con sus acciones y a exigir su respeto. Este derecho comprende, entre otras cosas, los siguientes derechos: (i) A unas comunicaciones orientadas siempre a la verdad, tanto en la intención como en el resto del proceso informativo. (ii) A acceder a las verdades necesarias para la realización humana, como lo son los conocimientos sobre una norma moral objetiva y sobre la verdad religiosa. (iii) A acceder a los conocimientos personales, familiares y culturales que forjan la propia identidad. (iv) A acceder a los conocimientos científicos que actualmente pertenecen al patrimonio de la humanidad. (v) A acceder a la información pública de actualidad, primero del contorno más inmediato, y luego del mundo entero.

Además, todo ser humano por naturaleza debe buscar la verdad. Quien la posee debe honrarla y comunicarla cuando la justicia lo exija. Las comunicaciones deben difundir los hechos a partir de la verdad, esto es, deben dar una imagen verdadera de las cosas y deben ellas mismas tener su propia verdad intrínseca. Por norma general, las comunicaciones deben darse dentro en un contexto de veracidad (las excepciones serían los juegos, las bromas, etc. donde se presupone la posibilidad de lo falso). Por ello, en los contextos de veracidad las informaciones deben comunicarse con la autenticidad, sinceridad, objetividad, relevancia, integridad, precisión y honestidad exigidas por la 
justicia. La orientación a la verdad en la comunicación debe darse tanto en la intención como en los actos. No hay derecho para expresar lo que se sabe o considera falso, salvo en los contextos comunicativos de enunciado falso.

En rigor, el deber jurídico no es de decir siempre la verdad, pues la verdad es difícil de alcanzar; el deber jurídico consiste en la veracidad, en no hablar intencionalmente contra lo que se piensa, en un mínimo de cuidado por no decir mentiras. La intensidad del deber de veracidad varía en muchos casos. El deber de respetar y decir la verdad es más intenso cuando: (i) Más cierta sea o deba ser la verdad conocida. (ii) Exista una responsabilidad cualificada por motivo de profesión. (iii) Exista una responsabilidad convencional o voluntariamente adquirida, como un juramento. (iv) De propósito se transmite la información con visos altos de veracidad. (v) Se prevea una mayor difusión del mensaje. (vi) El informador transmita su mensaje desde un puesto al que solo puedan acceder informadores titulados o se presupongan serios estudios en las respectivas ciencias. En general, la obligación de decir la verdad es de medio. Excepcionalmente la obligación es de resultado, como la del que jura decir lo que conoce o la del juez que en su sentencia debe decir la verdad sobre el asunto litigioso.

b) Elprincipio de la objetividad espropio de toda comunicación. Este principio ha sido sumamente cuestionado porque ningún sujeto es absolutamente objetivo: por el mismo hecho de ser sujeto, tiene una visión subjetiva del mundo y de los hechos. Quizá por ello la ley omite hablar de objetividad en las comunicaciones. Pese a este aparente obstáculo, sería un absurdo proclamar que la gente tiene derecho a decir cualquier cosa sobre los hechos que informa. Siempre se requiere un mínimo de objetividad. ¿Qué es la objetividad? Objetividad es la transmisión de la realidad tal cual es. Quien informa deberá hacerlo con la prudencia debida, procurando informar con la objetividad que le sea posible, dentro de la honesta y reconocida subjetividad. La objetividad implica dar cuenta de los acontecimientos en su contexto, sin aislarlos de la realidad, de tal manera que el receptor comprenda a fondo y pueda formarse una correcta opinión de la realidad. Son contrarias a la objetividad las comunicaciones alimentadas por fáciles entusiasmos o por alarmismos injustificados. Como dijimos, la LOC no habla de objetividad, pero no deja a merced de los informadores que informen lo que quieran, sino que pone un alto estándar de contextualidad (art. 22) y de contrastación de las diferentes fuentes (art. 22), lo que tiene por finalidad la de lograr la mayor objetividad posible en la comunicación, dentro de la legítima subjetividad. Por tanto, el principio de objetividad se encuentra tácitamente consagrado en la ley.

c) El principio de relevancia señala, en primer lugar, que ha de transmitirse la información que posea relevancia sustancial para el ser humano. Para determinar cuál es lainformación relevante en cada comunicación, debe considerarse la naturaleza de: (i) El informador, su profesión y demás condiciones. (ii) El receptor, su edad, sexo y demás condiciones. (iii) La finalidad propia de la comunicación. (iv) Los medios de comunicación usados. (v) La naturaleza del contexto comunicativo. Así, por ejemplo, la información relevante sobre la ciencia es muy distinta ante un público infantil, ante 
el público general o ante el mundo científico: son tres estándares distintos. Aplicando este principio, el art. 1.in fine de la LOC (para salvarlo de la inconstitucionalidad) debería interpretarse en el sentido de que se ha de tener como ilegítima la omisión deliberada y recurrente de difundir una información relevante con la sola intención de confundir o engañar al público, cuando la omisión en efecto confunda o engañe al público. Por otro lado, el art. 7 de la LOC define como relevante un cierto tipo de información.

d) El principio de integridad, por el que la persona que comunica una información debe transmitir todos los datos relevantes que posee o debe poseer. Son especialmente contrarias a derecho las omisiones calculadas que cambian el sentido de la comunicación. En este sentido el art. 10.3.b de la LOC prohíbe «abstenerse de omitir y tergiversar intencionalmente elementos de la información u opiniones difundidas». El principio también se encuentra tácitamente recogido en el art. 22.

e) El principio de precisión (o no confusión), por el que quien comunica una información debe procurar transmitirla usando un lenguaje adecuado para expresar fidedignamente lo que se informa. Son especialmente contrarios al derecho: (i) las inexactitudes calculadas que cambian el sentido de la comunicación; y (ii) todo lo que genera confusión. El art. 22 menciona que «la precisión implica recoger y publicar con exactitud los datos cuantitativos y cualitativos que se integran a la narración periodística de los hechos» y luego define qué son estos datos cualitativos dando varios ejemplos. La precisión es la exactitud. El art. 22 in fine señala que una manifestación suya es mostrar los datos verificados como verificados, y los no verificados «como suposiciones»; esto es válido para la mayoría de informaciones, pero no para las cosas evidentes. No hay que probar que el agua moja.

f) El principio de autenticidad, por el que quien interviene en una relación comunicacional en general debe presentarse sinceramente como quien es. El anonimato en las comunicaciones es siempre una excepción, pero es posible y está consagrado en varias normas (por ejemplo, en la misma Constitución de la República del Ecuador, art. 20, que habla del secreto de la fuente). Son especialmente contrarios al derecho la duplicidad, la simulación dolosa y toda forma de hipocresía en las comunicaciones que causen daño informativo. En este sentido, el art. 22 destaca que han de ser especialmente auténticas (mostrarse tal como son) las fuentes que tienen «un interés específico o vinculación de orden electoral, política, económica o de parentesco en relación a las personas o a los hechos que forman parte de la narración periodística», por lo que «esto deberá mencionarse como dato de identificación de la fuente».

g) El principio de oportunidad, consagrado en el art. 10, num. 3, lit. a), de la LOC para la información de relevancia pública (no mencionado en el art. 22), implica que cada comunicación tiene su tiempo. Ello se manifiesta, por ejemplo, en las franjas horarias de televisión para todo público o para público cualificado. Son criterios 
para definir el tiempo de las comunicaciones: (i) el público al que está dirigido; (ii) el contexto comunicativo; (ii) la actualidad de la noticia; (iv) la importancia de la noticia, entre otras cosas.

h) Por el principio de honestidad en toda comunicación las partes deben actuar honestamente y transmitir mensajes honestos. La actuación es honesta cuando busca sinceramente el bien. Comprende todo el campo de la libertad: desde la intención de la persona hasta la realización de lo querido. Son comunicaciones deshonestas las que dañan ilegítimamente a otro, las que violentan los derechos de terceros, las leyes morales o la dignidad del ser humano.

i) El principio de belleza es el menos explorado de todos los principios de la información, y prácticamente ha quedado reservado al tema de las obras de arte y la cultura, que es obvio hay que proteger. Mientras más bello es algo, mayor grado de protección ha de dársele. Sin embargo, es un principio general que aplica a toda la comunicación. Ha de entenderse bien qué significa la belleza: belleza es aquel bien verdadero que está correcta y adecuadamente ordenado a las potencias humanas y las satisface; es aquella verdad buena que la persona puede contemplar. Quien comunica algo ha de facilitar la contemplación de la verdad; es decir, la comunicación de lo verdadero debe ser adecuada a la forma de ser y de recibir la información del receptor. Contrarían especialmente al principio de belleza: (i) la comunicación de la verdad de forma desagradable; (ii) la comunicación de lo falso de forma agradable; (iii) la degradación de lo bello.

Advertimos que todos estos principios son de aplicación gradual. La intensidad con que deben aplicarse depende del tipo de mensaje y de sus circunstancias espacio-temporales. Por ejemplo, existen diversos grados de exigencia de la verdad: no hay el mismo nivel de exigencia de veracidad en una conversación entre amigos que se hace en un club privado, que al rendir un testimonio ante el juez bajo juramento; no debe exigirse la misma precisión a un periodista que a un perito. En especial, no se debe exigir a las noticias de primera hora la misma objetividad, precisión, relevancia, etc. que a las que se publican una semana después de los eventos, cuando los periodistas han tenido tiempo de hacer mayores averiguaciones. Si el art. 22 de la LOC no se aplicara gradualmente, atendiendo caso por caso, se cometería un abuso del derecho. 


\section{Referencias}

Bell Mallen, I., Corredoira y Alfonso, L. \& Cousido, P. (1992). Derecho de la Información, t. I. Madrid: Colex.

Constitución de la República del Ecuador (2008). Registro Oficial 449 de 20-X-2008.

Desantes Guanter, J. M., Bel Mallen, I., Corredoira y Alfonso, L., Cousido González, M.P. \& Y García Sanz, R. M. (1994). Derecho de la información, t. II. Madrid: Colex.

Ley Orgánica de Comunicación (2013). Suplemento del Registro Oficial 22 de 22-VI-2013.

Nieto Tamargo, A. (XII-1968). Participación y empresa periodística. Nuestro Tiempo, 174, pp. 1-23.

Nieto Tamargo,A.(IX-1969). Periodistayparticipación.Nuestro Tiempo, 183,pp. 173-219.

Reglamento a la Ley Orgánica de Comunicación (2014). Decreto Ejecutivo 214, publicado en el Suplemento del Registro Oficial de 170 de 27-I-2014.

Riofrío Martínez-Villalba, J.C. (2008). El derecho de los secretos. Bogotá: Temis.

Riofrío Martínez-Villaba, J.C. (2013). El valor del preámbulo de la Constitución ciudadana. Actualidad jurídica, 51, pp. 3-5.

Riofrío Martínez-Villalba, J.C. (ed.). (2014). Régimen de la Comunicación. Quito: CEP. 